\title{
Assessment of NSAIDs as potential inhibitors of the fatty acid amide hydrolase I (FAAH-1) using three different primary fatty acid amide substrates in vitro
}

Julius T. Dongdem ${ }^{1,2^{*}} \mathbb{D}$, Gideon K. Helegbe ${ }^{1} \mathbb{D}$, Kwame Opare-Asamoah ${ }^{3} \mathbb{D}$, Cletus A. Wezena ${ }^{4}$ and Augustine $\mathrm{Ocloo}^{5}$ (D)

\begin{abstract}
Background: Pain relief remains a major subject of inadequately met need of patients. Therapeutic agents designed to treat pain and inflammation so far have low to moderate efficiencies with significant untoward side effects. FAAH-1 has been proposed as a promising target for the discovery of drugs to treat pain and inflammation without significant adverse effects. FAAH-1 is the primary enzyme accountable for the degradation of AEA and related fatty acid amides. Studies have revealed that the simultaneous inhibition of COX and FAAH-1 activities produce greater pharmacological efficiency with significantly lowered toxicity and ulcerogenic activity. Recently, the metabolism of endocannabinoids by COX-2 was suggested to be differentially regulated by NSAIDs.

Methods: We analysed the affinity of oleamide, arachidonamide and stearoylamide at the FAAH-1 in vitro and investigated the potency of selected NSAIDs on the hydrolysis of endocannabinoid-like molecules (oleamide, arachidonamide and stearoylamide) by FAAH-1 from rat liver. NSAIDs were initially screened at $500 \mu \mathrm{M}$ after which those that exhibited greater potency were further analysed over a range of inhibitor concentrations.

Results: The substrate affinity of FAAH-1 obtained, increased in a rank order of oleamide $<$ arachidonamide $<$ stearoylamide with resultant $V_{\max }$ values in a rank order of arachidonamide $>$ oleamide $>$ stearoylamide. The selected NSAIDs caused a concentration-dependent inhibition of FAAH-1 activity with sulindac, carprofen and meclofenamate exhibiting the greatest potency. Michaelis-Menten analysis suggested the mode of inhibition of FAAH-1 hydrolysis of both oleamide and arachidonamide by meclofenamate and indomethacin to be noncompetitive in nature.
\end{abstract}

Conclusion: Our data therefore suggest potential for study of these compounds as combined FAAH-1-COX inhibitors. Keywords: Arachidonamide, Affinity, FAAH-1, Hydrolysis, Oleamide, Arachidonamide, Stearoylamide, Inhibition, NSAIDs, Mode

\footnotetext{
* Correspondence: julius.dongdem@uds.edu.gh; jtdongdem@gmail.com 'Department of Biochemistry and Molecular Medicine, School of Medicine, University for Development Studies, Tamale-Campus, Tamale, Ghana

${ }^{2}$ School of Life Sciences, University of Nottingham Medical School, NG7 2UH Nottinghamshire, UK

Full list of author information is available at the end of the article
}

(c) The Author(s). 2021 Open Access This article is licensed under a Creative Commons Attribution 4.0 International License, which permits use, sharing, adaptation, distribution and reproduction in any medium or format, as long as you give appropriate credit to the original author(s) and the source, provide a link to the Creative Commons licence, and indicate if changes were made. The images or other third party material in this article are included in the article's Creative Commons licence, unless indicated otherwise in a credit line to the material. If material is not included in the article's Creative Commons licence and your intended use is not permitted by statutory regulation or exceeds the permitted use, you will need to obtain permission directly from the copyright holder. To view a copy of this licence, visit http://creativecommons.org/licenses/by/4.0/. The Creative Commons Public Domain Dedication waiver (http://creativecommons.org/publicdomain/zero/1.0/) applies to the data made available in this article, unless otherwise stated in a credit line to the data. 


\section{Introduction}

Several therapeutic agents have been designed to address different forms of pain, yet pain relief remains an area of significant unmet patient need [1,2]. Drugs administered to treat pain and inflammation presently have low to moderate efficiencies with significant untoward side effects such as gastrointestinal bleeding, ulceration, renal dysfunction, nausea and vomiting.

Fatty acid amide hydrolase I (FAAH-1) has been proposed as a promising target for the discovery of drugs to treat pain, inflammation and other pathologies $[3,4]$. FAAH-1 is the primary enzyme that is responsible for the degradation of $\mathrm{N}$-Arachidonoyl ethanolamide (Anandamide, AEA) and related fatty acid amides which constitute a group of biologically active endogenous amides $[5,6]$. Inhibition of FAAH-1 results in the accumulation of AEA and other endocannabinoid-like molecules in the central and peripheral nervous systems where they act as ligands of cannabinoid $\left(\mathrm{CB}_{1}\right.$ and $\left.\mathrm{CB}_{2}\right)$ receptors. Similar to $\Delta 9$-tetrahydrocannabinol (THC), AEA is a partial agonist at both $\mathrm{CB}_{1}$ and $\mathrm{CB}_{2}$ transmembrane receptors - members of the G-protein-coupled receptor superfamily [7-9] however, in contrast to THC, AEA also stimulates the transient receptor potential vanilloid receptor type 1 (TRPV1) [10-12]. AEA exhibits cannabimimetic effects at the cannabinoid receptors [13]. Palmitoyl ethanolamide has also been reported to be active at peroxisome proliferator-activated receptors (PPARs) as well as vanilloid receptors. The primary fatty acid amides (PFAMs) such as oleamide, arachidonamide, stearoylamide, stearoyl ethanolamide, palmitamide, etc.) are also important molecules controlling sleep, angiogenesis, locomotion, convulsions and inhibition of gap junction formation among several other functions [14-18].

Although the major current strategy for drug development is to design compounds that are selective for a given target, compounds that target more than one biochemical process may have superior efficacies with better safety profiles compared with standard selective compounds. This can be achieved by administering the drugs either separately or in single tablets made of more than one active ingredient. The disadvantage in both cases is the potential for a large pharmacokinetic variability that is equivalent to the concomitant administration of separate drugs. The alternative to avoid these drawbacks is to develop drugs that target more than one molecular mechanism [19]. Inhibition of COX-1 and -2 at the first committed step of prostanoid and other eicosanoid biosynthesis from arachidonic acid (AA) underlies the analgesic action of non-steroidal antiinflammatory drugs (NSAIDs) [20-23]. NSAIDs constitute a class of chemically diverse compounds that provide analgesic, antipyretic and anti-inflammatory effects. The fatty acid metabolic end-products of the induction of the
COX cascade by a wide range of stimuli are prostaglandins $\left(\mathrm{PGD}_{2}, \mathrm{PGE}_{2}, \mathrm{PGF}_{2 \alpha}\right.$ and $\left.\mathrm{PGI}_{2}\right)$. AA embedded in cell membranes as esters of phospholipids is the precursor of prostaglandins (PGs). AA is made available by action of several enzymes including $\mathrm{cPLA}_{2} / \mathrm{sPLA}_{2}, \alpha \beta$ Hydrolase 4 and GDE [24]. Once induced, COX, LOX and cytochrome P450 enzymes convert available AA to various eicosanoids. These eicosanoids are known essential physiological and pathophysiological mediators implicated in a wide scope of therapeutic interest such as in inflammation, pain, cancer, glaucoma, male sexual dysfunction, osteoporosis, cardiovascular disease, labour, asthma, etc [25]

Selected NSAIDs have also been reported to inhibit FAAH-1 activity from mouse and rat preparations [26]. Studies in animal models have revealed that the simultaneous inhibition of COX and FAAH-1 activities produce greater pharmacological efficiency with significantly lowered toxicity and ulcerogenic activity associated with COX inhibitors [27, 28]. More recently, the metabolism of endocannabinoids by COX-2 was suggested to be differentially regulated by NSAIDs resulting in antinociceptive effects mediated via cannabinoid receptors [29-32]. Apart from catalysing the formation of PGs from AA, COX-2 also catalyses the formation of prostaglandin-glycerol esters and prostaglandin ethanolamines from 2-arachidonoyl glycerol (2-AG) and AEA respectively [30, 33-35]. Since COX-2 is a significant target of NSAIDs, COX-2 inhibition can reduce this mechanism of endocannabinoid metabolism to enhance their concentrations in vivo $[36,37]$. Moreover, rapid reversible inhibitors of COX-2 selectively inhibit the oxygenation of 2-AG and AEA with much higher potencies for AA, a phenomenon referred to as substrate selective effect $[30,38]$. The fact that selected NSAIDs inhibit AEA and 2-AG metabolism via FAAH-1 and COX inhibition in vivo, suggests that at the appropriate concentrations, NSAIDs may co-regulate the activity of both COX and FAAH-1 enzymes which make them better suitable therapeutic agents $[39,40]$. Since cannabinoids possess anti-inflammatory, antinociceptive, analgesic, anti-tumour and immunosuppressive properties, inhibitors of endocannabinoid degrading enzymes (FAAH-1, FAAH-2, NAAA, COX-2, LOX, MAGL) may be of therapeutic significance via augmentation of endocannabinoid and endocannabinoid-like molecule accumulation in vivo. Based on this previous knowledge, it is essential to conduct further investigations on the ability of other NSAIDs to inhibit FAAH-1 deamination of endocannabinoid and endocannabinoid-like molecule substrates (e.g. oleamide, arachidonamide, stearoylamide and stearoyl ethanolamide among others) for the reason that NSAIDs with both inhibitory capabilities (on COX and FAAHs) will synergistically enhance therapeutic efficacies. The aim of this study therefore, was to assess 
pharmacological profiles of FAAH-1 with regards to potential substrates and inhibitors. The investigation was specifically designed to assess the potency of selected NSAIDs on the hydrolysis of oleamide, arachidonamide and stearoylamide by FAAH-1.

\section{Materials and methods}

FAAH-1 activity was studied in rat liver homogenate.

\section{Preparation of rat liver homogenate}

Liver obtained from male Wister rats (150-250 g, Charles River Laboratories, Wilmington, USA) which had been stored at $-40^{\circ} \mathrm{C}$ was thawed. A volume of 6 $\mathrm{ml} / \mathrm{g}$ wet weight of rat liver was homogenized in $0.2 \mathrm{M}$ potassium phosphate buffer, $\mathrm{pH} 7.4$ using a hand held homogenizer (Ultra-turrax) (Merck KGaA, Darmstadt, Germany). The resulting mixture was centrifuged at 250 g for $10 \mathrm{~min}$ after which the pellet obtained was rehomogenised and centrifuged as aforementioned. The supernatants were combined and centrifuged at 20,000 g for $30 \mathrm{~min}$, after which the membrane containing pellet was re-suspended in $1: 1^{\mathrm{w}} / \mathrm{v} 0.2 \mathrm{M}$ potassium phosphate buffer, $\mathrm{pH} 7.4$, and stored in $1 \mathrm{ml}$ aliquots at $-40^{\circ} \mathrm{C}$.

\section{Assay of FAAH-1 activity}

FAAH-1 activity was assayed essentially as described previously [41]. Briefly, rat liver homogenate was preincubated at $37^{\circ} \mathrm{C}$ with shaking $(50 \times 10 \mathrm{rpm})$ for $10 \mathrm{~min}$ in $0.2 \mathrm{M}$ phosphate buffer, $\mathrm{pH} 7.4$ in 96 -well microtitre plates (Thermo Scientific Inc., Waltham, USA) prior to substrate addition and incubation at $37^{\circ} \mathrm{C}$ for $30 \mathrm{~min}$. The $100 \mu \mathrm{l}$ total assay reaction mixtures were halted with an equivalent volume of o-phthaldehyde (OPA) developing solution $(0.4 \mathrm{M}$ potassium phosphate buffer, $\mathrm{pH}$ 11.5) and incubated further at $37^{\circ} \mathrm{C}$ for $15 \mathrm{~min}$ before assessing fluorescence using a FLUOstar Galaxy (Excitation $390 \mathrm{~nm}$, Emission 450-10 nm) (BMG LABTECH GmbH, Ortenberg, Germany). Substrate blank and a control containing $0.2 \mathrm{M}$ phosphate buffer, $\mathrm{pH} 7.4$, were incorporated into the experiments.

Subsequently, the influence of ethanol concentrations on the ability of particular NSAIDs e.g. indomethacin (SIGMA-ALDRICH, Poole, UK) was assessed by varying the volume of inhibitor solution added, using both absolute ethanol and buffer blanks to account for background influences on enzymatic activity.

\section{Protein assay}

Homogenate protein content was measured by modifications of the method described [42] using $200 \mu \mathrm{l}$ of different concentrations of bovine serum albumin $(0,25,50$, $100,150,200,300 \mu \mathrm{g} / \mathrm{ml}$ ) as standard and $200 \mu \mathrm{l}$ of 0.5 $\mathrm{M} \mathrm{NaOH}$ as blank (Fig. SS1). Briefly, $50 \mu \mathrm{l}$ of each membrane fragment in $5 \mathrm{ml}$ of $0.5 \mathrm{M} \mathrm{NaOH}$ was prepared, after which $200 \mu \mathrm{l}$ of each dilution was added to $1 \mathrm{ml}$ of solution A $(100 \mathrm{ml}$ of $2 \%$ sodium carbonate and $1 \mathrm{ml}$ each of both sodium potassium tartrate and copper sulphate). The solutions were mixed and allowed to stand at room temperature. After $10 \mathrm{~min}, 100 \mu \mathrm{l}$ of dilute Folin Ciocalteau's reagent 1:1 $\mathrm{dd}_{2} \mathrm{O}$ was added and mixed immediately. The absorbance of each sample was read at a wavelength of $700 \mathrm{~nm}$ following incubation at room temperature for $1 \mathrm{~h}$. Relative absorbance of each sample was entered into GraphPad prism and analysed. The protein concentration of preparations were interpolated from the standard (Fig. SS1), using non-linear, second order polynomial (quadratic) graph of the standards.

\section{Statistical analysis}

Data obtained were entered into a Microsoft Excel 2010 spread sheet and analysed with GraphPad Prism computer software programme (GraphPad Software Inc., San Diego, CA USA). Effect of $500 \mu \mathrm{M}$ concentration of NSAIDs (SIGMA-ALDRICH, Poole, UK) on each enzyme activity was analysed by removing the baseline line. Each specific activity was then plotted as percentage of control. Specific activity obtained at each inhibitor concentration for the concentration-inhibition curves were normalized and analysed using the inbuilt log (inhibitor) versus response variable slope (robust fit) and were constrained at the bottom $(=0.0 \%)$. Each specific activity was then plotted as percentage of the control. To determine the mode of inhibition, $\mathrm{V}_{\max }$ values were initially extrapolated from the $\left(\mathrm{NH}_{4}\right)_{2} \mathrm{SO}_{4}$ standard curve plotted using the inbuilt second order polynomial (quadratic) Michaelis-Menten enzyme kinetics. These values were then adjusted using the protein concentrations of the preparations obtained from the Lowry protocol [42] (Fig. SS1 and SS2).

\section{Results and discussion \\ Affinity of oleamide, arachidonamide and stearoylamide at $\mathrm{FAAH}-1$}

Several drugs are inhibitors of the most relevant enzymes since blocking these enzymes can kill a pathogen or correct a metabolic imbalance. To characterise an enzyme in the presence of inhibitors however, a good kinetic description of its activity is essential. Here, the ability of rat liver to hydrolyse oleamide, stearoylamide and arachidonamide was assessed by Michaelis-Menten analysis (Fig. 2). The resultant Michaelis-Menten constant $\left(\mathrm{K}_{\mathrm{m}}\right)$ and maximum velocity $\left(\mathrm{V}_{\max }\right)$ values obtained are summarized in Table 1. The substrate affinity of FAAH-1 increased in a rank order of oleamide $<$ arachidonamide < stearoylamide with resultant $\mathrm{V}_{\max }$ values in a rank order of arachidonamide $>$ oleamide $>$ stearoylamide (Fig. 1, Table 1). The kinetic values for FAAH-1 hydrolysis of oleamide obtained are consistent with 
Table $1 \mathrm{~K}_{\mathrm{m}}$ and $\mathrm{V}_{\max }$ values determined for rat liver FAAH-1 hydrolysis of three different fatty acid amides

\begin{tabular}{llll}
\hline FAAH-1 kinetics & Substrate & & \\
\cline { 2 - 4 } & Oleamide & Arachidonamide & Stearoylamide \\
\hline $\mathbf{K}_{\mathbf{m}}(\boldsymbol{\mu M})$ & $177.2 \pm 15.5$ & $44.9 \pm 7.0$ & $4.6 \pm 0.8$ \\
$\mathbf{V}_{\max }(\mathbf{n m o l} / \mathbf{m i n} / \mathbf{m g}$ protein) & $8.9 \pm 1.1$ & $10.1 \pm 3.0$ & $2.5 \pm 0.6$ \\
\hline
\end{tabular}

Data are mean \pm SEM (Standard Error of the Mean) of four separate preparations $(n=4)$ conducted in triplicate

previous observations. Similar $K_{m}$ and $V_{\max }$ values of $129 \mu \mathrm{M}$ and $15 \mathrm{nmol} \cdot \mathrm{min}^{-1}$. $\mathrm{mg}$ protein ${ }^{-1}$ from oleamide hydrolysis by FAAH-1 in rat liver preparations and a $\mathrm{K}_{\mathrm{m}}$ value of $179 \mu \mathrm{M}$ with FAAH-1 in rat brain were previously obtained compared with $\mathrm{K}_{\mathrm{m}}$ of $177.2 \pm 15.5 \mu \mathrm{M}$ and $\mathrm{V}_{\max }$ of $8.9 \pm 1.1 \mathrm{nmol} . \mathrm{min}^{-1}$.mg protein ${ }^{-1}$ obtained in our findings (Table 1) [41]. An affinity of $104 \mu \mathrm{M}$ and a $V_{\max }$ of $5.7 \mathrm{nmol} \mathrm{min}^{-1} \mathrm{mg}$ protein $^{-1}$ for rat liver FAAH-catalysed oleamide hydrolysis has been reported [44]. Additionally, an affinity of $37 \pm 7 \mu \mathrm{M}$ at $\mathrm{pH} 9$ for rat

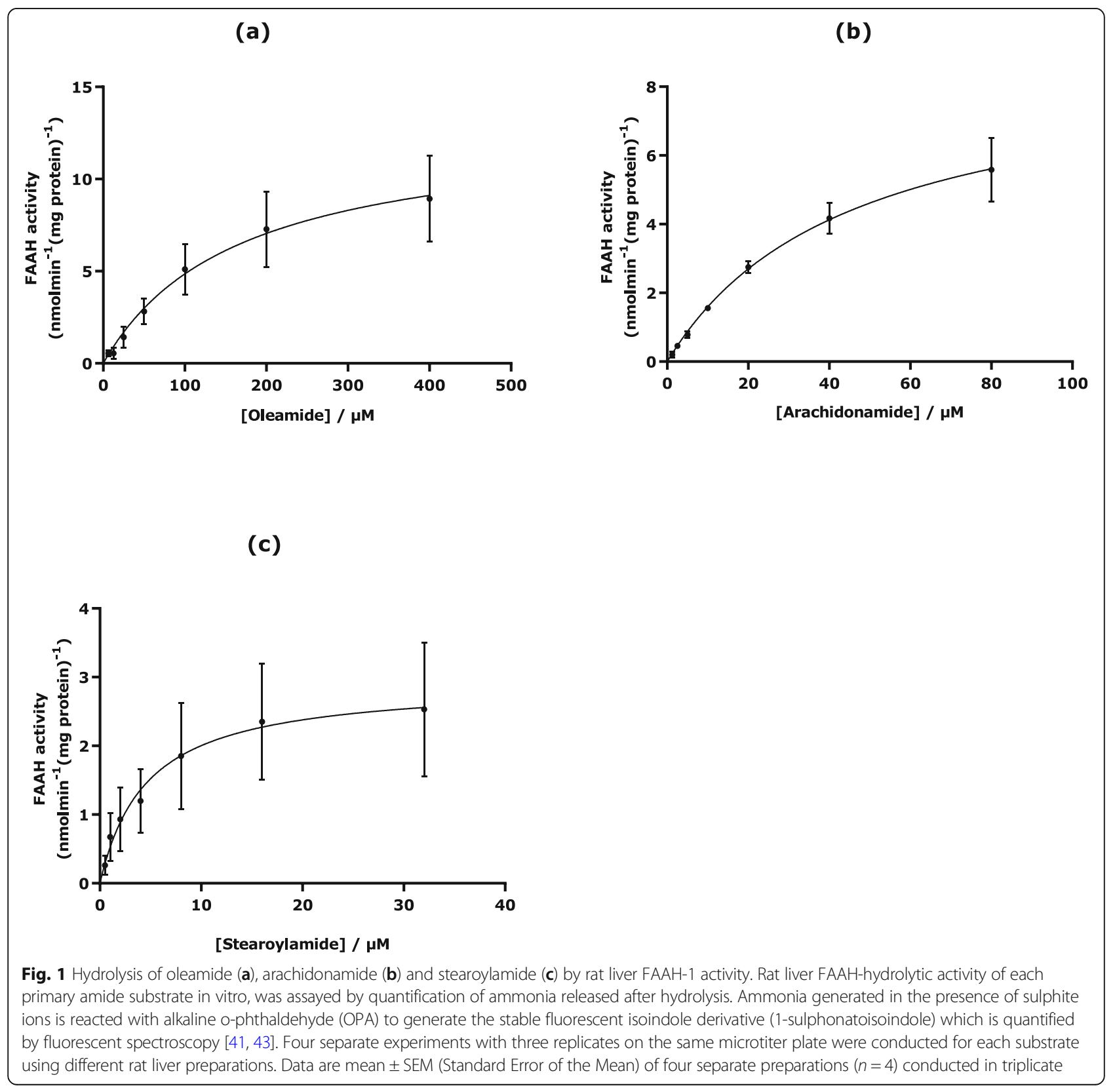


recombinant FAAH-catalysed oleamide hydrolysis has also been reported [45].

FAAH-1 has the ability to hydrolyse a wide range of unsaturated and, to a lesser extent, saturated PFAMs and other fatty acids e.g. oleamide and palmitoyl ethanolamide [46, 47]. In our findings, FAAH-1 capacity $\left(\mathrm{V}_{\max }\right)$ was $12 \%$ higher for arachidonamide compared with oleamide and $75 \%$ higher than that for stearoylamide. This confirms the propensity of FAAH-1 to turn over polyunsaturated PFAMs particularly with cis double bonds at higher rates than monounsaturated and saturated PFAMs and is consistent with literature (Fig. 1) [48, 49].

Screening of NSAIDs as potential inhibitors of oleamide, arachidonamide and stearoylamide hydrolase activity

Following pilot experiments that revealed indomethacin to have an $\mathrm{IC}_{50} \sim 500 \mu \mathrm{M}, 16$ selected NSAIDs were screened at $500 \mu \mathrm{M}$ (Fig. 2) for ability to inhibit FAAH-1 in order to assess pharmacological profiles of rat liver FAAH-catalysed hydrolysis of the three PFAMs assayed at a concentration $\geq \mathrm{K}_{\mathrm{m}}$ value determined [41, 43]. NSAI Ds were randomly selected based on availability and considering what had not been reported while using a few that had been reported against FAAH-1 as reference standards. Meclofenamic acid exhibited complete inhibition of FAAH-1 activity when oleamide was used as substrate. Sulindac, diclofenac, carprofen, ketorolac and diflunisal exhibited a higher degree of inhibition of rat liver FAAH-1 activity by inhibiting oleamide hydrolysis to below $50 \%$ of control (Fig. 2). Ibuprofen, sulindac sulphone, indomethacin and dipyrone were moderate inhibitors of oleamide hydrolysis and inhibited FAAH-1 activity to between 50 and $70 \%$ of control. Tolmetin, salicyluric acid, salicylic acid (diluted in $0.2 \mathrm{M}$ potassium phosphate buffer) evoked weak inhibitory ability of FAAH-1 activity to between 70 and $100 \%$ of control. Acetaminophen and acetyl salicylic acid appeared to enhance enzyme activity.

Acetaminophen is reported to be metabolised to $\mathrm{N}$ arachidonoylaminophenol (AM404) via FAAH-1 [50]. AM404 then inhibits FAAH-1 activity and prevents AEA metabolism. Thus, FAAH-1 is active until concentrations of AM404 are high enough to inhibit its function. AEA accordingly activates platelets, however, the process is unaffected by acetyl salicylic acid, thus it is possible it did not affect rat liver FAAH-1 activity [51]. The differences in reaction of FAAH-1 to specific compounds (e.g. ketorolac or ibuprofen) might be due to differences in structures, their sites of binding to FAAH-1 and how this affects substrate entry and binding at the catalytic sites [52-55].

\section{Effect of vehicle controls on FAAH activity}

As the NSAIDs are differently soluble in aqueous compared to organic solution, the effect of a range of concentrations of the vehicle ethanol was assessed using indomethacin as a reference compound. Indomethacin evoked a concentration-dependent inhibition of FAAH-1 activity in $\mathrm{pIC}_{50}$ values between 15,20 or $25 \%$ ethanol concentrations (Fig. 3). Tukey's multiple comparisons

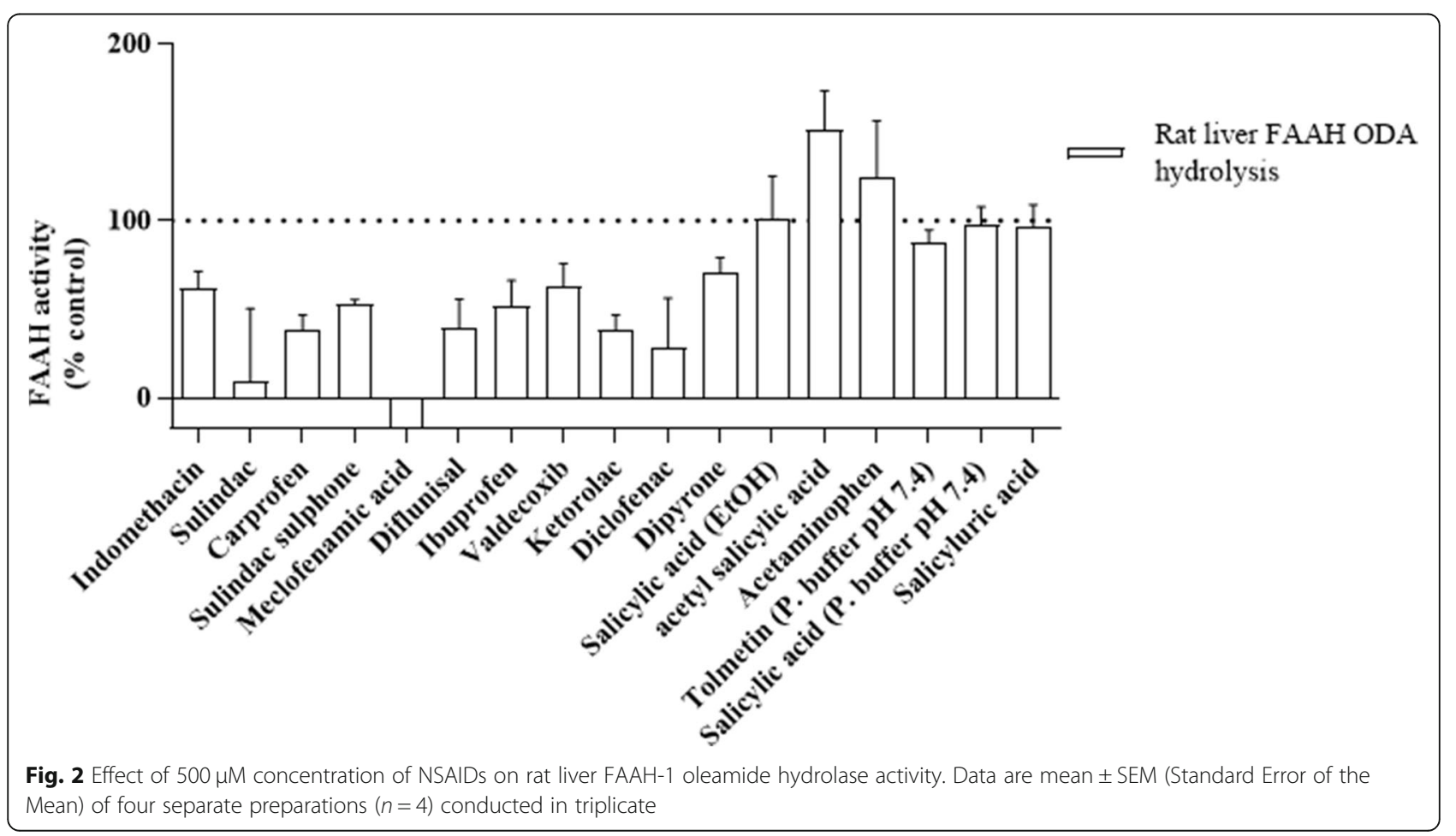




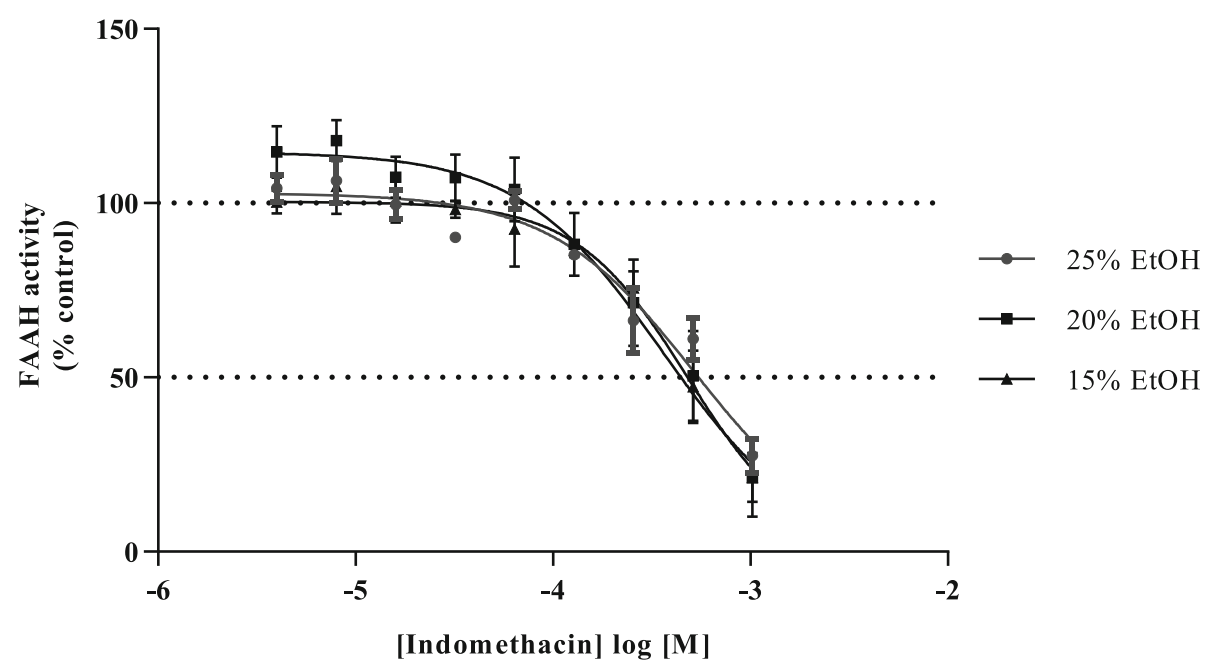

Fig. 3 Effect of 15, 20 and 25\% ethanol on the inhibition of rat liver oleamide hydrolase activity by indomethacin. Data are mean \pm SEM (Standard Error of the Mean) of four separate preparations $(n=4)$ conducted in triplicate

test with single pooled variance, $p=0.7250, p<0.05$ as significantly different, $\mathrm{CI}=95 \%$ indicated no significant difference between pIC50 values obtained (Table 2). This implies that, within the experimental limits, ethanol had no effect on the inhibitory function of indomethacin, albeit with a reduced capacity for basal oleamide hydrolysis of $95 \pm 1,78 \pm 1$ and $76 \pm 4 \%$ of control for 15,20 and $25 \%$ assay ethanol respectively consistent with earlier reports that butanol reduced FAAH-1 activity by 30 to $50 \%$ but did not affect the enzyme response to inhibitors [40].

\section{Concentration-dependence of rat liver FAAH-1 oleamide hydrolase inhibition}

NSAIDs selected on the basis of the greater levels of inhibition at $500 \mu \mathrm{M}$ were examined over a range of concentrations in absolute ethanol, from $4.0 \times 10^{-6}$ to $1.024 \times 10^{-3} \mathrm{M}$ (Fig. 4). These exhibited concentrationdependent inhibition of FAAH-1 oleamide hydrolase activities. The order of inhibitory potency against rat liver FAAH-1 hydrolysis of oleamide was sulindac $>$ carprofen $>$ meclofenamic acid $>$ sulindac sulphone $>$ indomethacin $>$ diflunisal $>$ ibuprofen $>$ valdecoxib $>$ ketorolac $>$ diclofenac $>$ dipyrone (Table 3 ). The remaining NSAIDs

Table 2 Potency of indomethacin in the presence of different concentrations of ethanol

\begin{tabular}{llll}
\hline & $\mathbf{1 5 \%}$ EtOH & $\mathbf{2 0} \% \mathbf{E t O H}$ & $\mathbf{2 5 \%}$ EtOH \\
\hline plC50 & $3.4 \pm 0.1$ & $3.5 \pm 0.1$ & $3.4 \pm 0.1$ \\
FAAH-1 activity (\%) & $95 \pm 1$ & $78 \pm 1$ & $76 \pm 4 \%$
\end{tabular}

Data are mean \pm SEM (Standard Error of the Mean) of four separate preparations $(n=4)$ conducted in triplicate assayed exhibited very similar potencies ( $\mathrm{pIC}_{50}$ values) against activity of FAAH-1. The inhibition exhibited by the selected NSAIDs to FAAH-1 activity (Fig. 4, Table 3) is consistent with earlier studies although under different conditions [26, 39, 56, 57]. The rank order of potency displayed by NSAIDs screened at $500 \mu \mathrm{M}$ was not exactly the same when the $\mathrm{pIC}_{50}$ values were examined. Earlier findings indicate that NSAID inhibition of FAAH-1 activity is $\mathrm{pH}$ dependent [58] with a $\mathrm{pH}$ optimum of $\sim 9[46,59-63]$. The rank order of NSAIDs reported for potency against rat brain FAAH-1 activity at $\mathrm{pH} 7.4$ was; indomethacin $\left(\mathrm{pIC}_{50}=4.18\right) \approx$ carprofen $\left(\mathrm{pIC}_{50}=4.10\right)>$ ibuprofen $\left(\mathrm{pIC}_{50}=3.1\right)$ and is similar to our findings however, indomethacin was less effective than carprofen and more potent than ibuprofen [52]. Other studies found apparently biphasic $\mathrm{pH}$ dependence of FAAH AEA metabolism using brain microsomes [64].

\section{Mode of inhibition of FAAH-1 metabolism by meclofenamic acid and indomethacin}

To date, little has been reported on the mode of inhibition of NSAIDs on FAAH-catalysed hydrolysis of endocannabinoids and endocannabinoid-like molecules [26, 52]. Hence, meclofenamic acid and indomethacin were selected for further mechanistic investigation as the former evoked the greatest inhibition and the latter has previously been examined extensively in the literature [26].

Michaelis-Menten analysis indicated no significant changes in substrate affinity $\left(\mathrm{K}_{\mathrm{m}}\right)$ values but with decreasing $\mathrm{V}_{\max }$ values (Fig. 5, Table 4), thus indicative of non-competitive type inhibition of FAAH activity by the two inhibitors (meclofenamic acid and indomethacin). This finding is consistent with similar findings that 


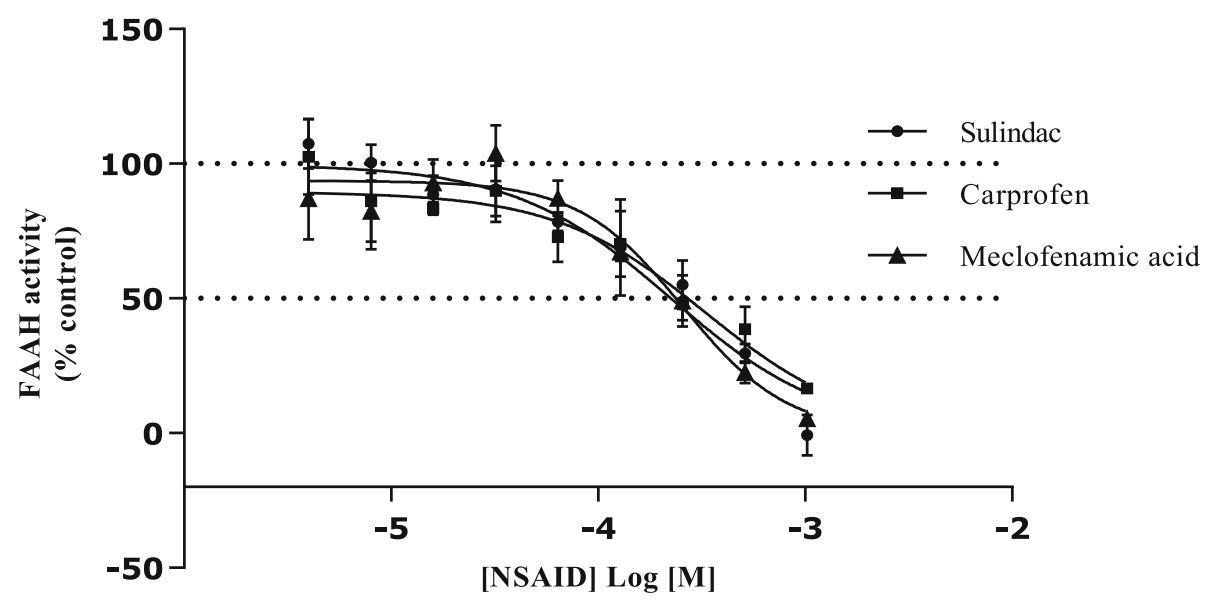

Fig. 4 Concentration-dependence of rat liver oleamide hydrolase activity inhibition. Data are mean \pm SEM (Standard Error of the Mean) of four separate preparations $(n=4)$ conducted in triplicate

FAAH is mechanistically allosteric in nature which is often associated with a non-competitive mode of inhibition, thus FAAH might also likely exhibit a noncompetitive mode of inhibition against these NSAIDs $[58,65,66]$. Unlike aspirin which is an irreversible inhibitor of COX enzymes, most other NSAIDs are reversible competitive inhibitors of the COX enzymes [67]. Previously scientists [38] found that meclofenamic acid and ibuprofen are also potent inhibitors of COX-2 suggestive of the potential for the design of a dual targeting inhibitor possibly in combination with URB597 an uncompetitive FAAH inhibitor [68], which may reduce the loading dose of NSAIDs with resultant fewer side effects.

\section{Therapeutic application of novel multi-target (FAAH/COX) analgesics}

In vivo increases in the levels of AEA resulting from FAAH-1 inhibition potentiates actions of COX inhibitors $[19,31]$ suggesting that, compounds that inhibit both FAAH and COX enzymes can be as effective as NSAIDs but with a reduced COX inhibitor 'load', consequently with accompanying reduction in the adverse effects

Table 3 Potencies of NSAIDs as inhibitors of rat liver oleamide hydrolase activity

\begin{tabular}{llll}
\hline NSAID & pIC50 (M) & NSAID & pIC50 (M) \\
\hline Sulindac & $3.65 \pm 0.08$ & Ibuprofen & $3.01 \pm 0.06$ \\
Carprofen & $3.58 \pm 0.09$ & Valdecoxib & $3.00 \pm 0.15$ \\
Meclofenamic acid & $3.57 \pm 0.06$ & Ketorolac & $2.91 \pm 0.07$ \\
Sulindac sulphone & $3.35 \pm 0.03$ & Diclofenac & $2.90 \pm 0.07$ \\
Indomethacin & $3.28 \pm 0.03$ & Dipyrone & $2.77 \pm 0.07$ \\
Diflunisal & $3.15 \pm 0.04$ & &
\end{tabular}

Data are mean \pm SEM (Standard Error of the Mean) of four separate preparations $(n=4)$ conducted in triplicate associated with NSAIDs [19]. There is evidence to support the controversy that dual-action FAAH-COX inhibitors may be more useful in this aspect. In vitro evidence suggests that the metabolism of AEA by COX-2 might be the most predominant degradation pathway after blocking the major FAAH metabolic pathway. Combinations of URB597 and diclofenac have demonstrated synergistic analgesic interactions $[27,69]$. Also, in vivo synergistic effect was achieved by administration of a combination of AEA and rofecoxib. Local injection of AEA with NSAID (ibuprofen or rofecoxib) generated higher amounts of fatty acid ethanolamides [70]. Synergistic effects have also been reported after a systematic administration of URB597 and diclofenac in a mouse model of visceral pain [71]. Meclofenamic acid, carprofen and indomethacin are among the most potent inhibitors of the COX enzymes and at the same time FAAH-1 from our study [72-75]. Our in vitro results support the possibility of combined therapeutic agents being explored. This suggests that, a combination of FAAH inhibitors such as URB597 and the NSAIDs with dual inhibitory capability may have greater utility to treat pain with reduced NSAID load and may have enhanced efficacies and safety profiles.

\section{Conclusion}

We established inhibitory potencies of NSAIDs against rat liver FAAH-1 using oleamide, arachidonamide and stearoylamide as substrates. Substrate affinity of FAAH1 increased in a rank order of oleamide $<$ arachidonamide $<$ stearoylamide with resultant $V_{\max }$ values in a rank order of arachidonamide $>$ oleamide $>$ stearoylamide. Our Findings confirmed the propensity of FAAH1 to turn over polyunsaturated PFAMs particularly with cis double bonds at higher rates than monounsaturated 


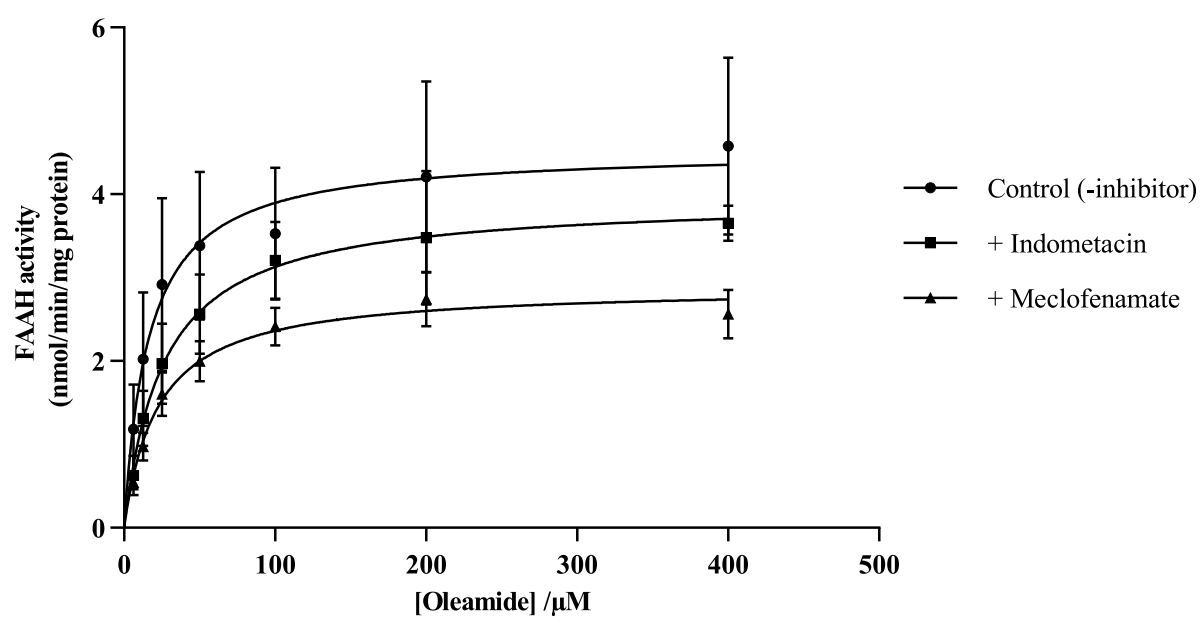

a)

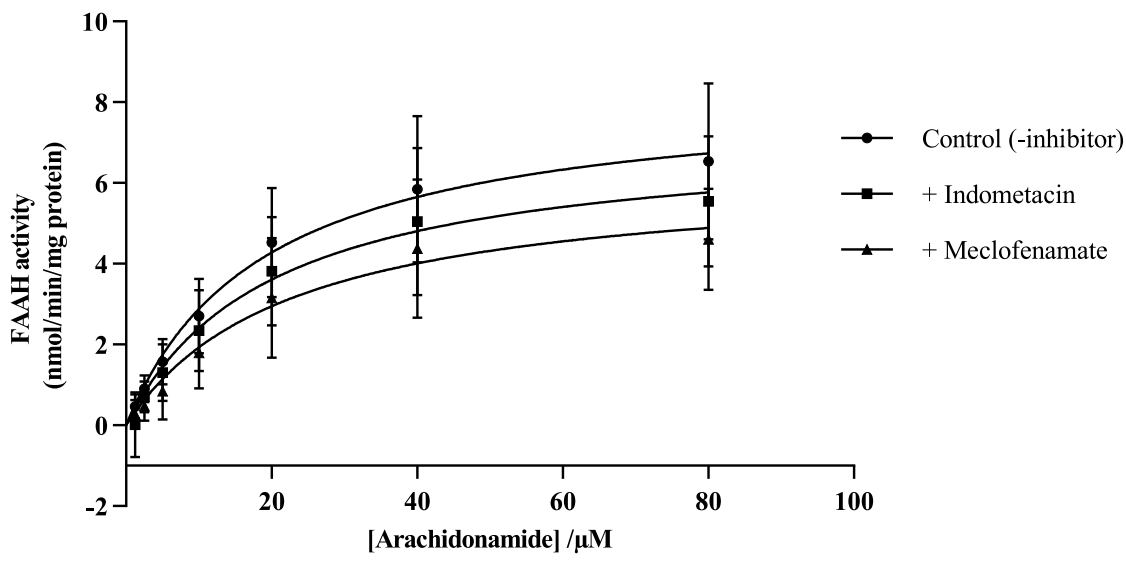

(b)

Fig. 5 Mode of inhibition of rat liver FAAH-1 hydrolysis of (a) oleamide and (b) arachidonamide by meclofenamic acid and indomethacin. Data are mean \pm SEM (Standard Error of the Mean) of four separate preparations $(n=4)$ conducted in triplicate

and saturated PFAMs. In the presence of meclofenamate or indomethacin, Michaelis-Menten analysis suggested a reduction in the $\mathrm{V}_{\max }$ of oleamide and arachidonamide hydrolysis, without significant alteration in substrate affinity, indicative of a non-competitive action of these inhibitors against FAAH-1 activity though more research is required for conclusive evidence. Even though, there was no indication of any selective action of NSAIDs, these results suggest potential for study of these compounds as combined FAAH-COX inhibitors.

Table 4 Mode of inhibition of rat liver FAAH-1 oleamide hydrolysis by indomethacin and meclofenamate

\begin{tabular}{llll}
\hline FAAH-1 Kinetics & $\mathbf{K}_{\mathbf{m}}(\boldsymbol{\mu M})$ & $\mathbf{V}_{\mathbf{m a x}}(\mathbf{n m o l} / \mathbf{m i n} / \mathbf{m g}$ protein) & Substrate \\
\hline Control & $18.4 \pm 3.5$ & $4.6 \pm 0.5$ & Oleamide \\
$+200 \mu \mathrm{M}$ indomethacin & $24.4 \pm 3.3$ & $3.8 \pm 0.4$ & Oleamide \\
$+100 \mu \mathrm{M}$ meclofenamate & $22.7 \pm 1.4$ & $2.9 \pm 0.1$ & Oleamide \\
Control & $19.8 \pm 2.0$ & $8.4 \pm 1.2$ & Arachidonamide \\
$+200 \mu \mathrm{M}$ indomethacin & $21.6 \pm 2.8$ & $7.2 \pm 0.9$ & Arachidonamide \\
$+100 \mu \mathrm{M}$ meclofenamate & $23.4 \pm 3.7$ & $6.7 \pm 1.0$ & Arachidonamide \\
\hline
\end{tabular}

Data are mean \pm SEM of triplicate assessments conducted on five transient transfects $(n=5)$ 


\section{Supplementary Information}

The online version contains supplementary material available at https://doi. org/10.1186/s40360-021-00539-1.

\section{Additional file 1.}

\section{Acknowledgements}

We thank Dr. Stephen P.H. Alexander, Dr. Simon P. Dawson, Dr. Michae Garle, Liaque Lateef, Nicola De Vivo and Monika Owen, all of the School of Life Sciences, University of Nottingham, UK for their support. We are grateful to our sponsors, Ghana Education Trust Fund (GETFund), Ghana and the University for Development Studies, Ghana for funding, and the University of Nottingham, UK, for providing the environment in which to conduct these studies.

\section{Authors' contributions}

J.T.D performed the experiments and drafted the manuscript. A. O, G.K.H, K.O-A and C.A.W contributed to the final version of the manuscript The author(s) read and approved the final manuscript.

\section{Funding}

The project was financed by GETFund.

\section{Availability of data and materials}

The datasets used and/or analysed during the current study are available from the corresponding author on reasonable request.

\section{Declarations}

\section{Ethics approval and consent to participate}

All methods were carried out in accordance with the relevant UKRIO (UK Research Integrity Office) guidelines and regulations for animal use in research and the Animals (Scientific Procedures) Act 19862 (ASPA) and guidance regulating the use of animals in scientific procedures. All experimental protocols were approved by the ethics committee of the School of Life Sciences, University of Nottingham Medical School, Queen's Medical Centre, UK. All experiments on animal parts were carried out in accordance with ARRIVE guidelines.

\section{Consent for publication}

Not applicable.

\section{Competing interests}

The authors declare no competing interests.

\section{Author details}

${ }^{1}$ Department of Biochemistry and Molecular Medicine, School of Medicine, University for Development Studies, Tamale-Campus, Tamale, Ghana. ${ }^{2}$ School of Life Sciences, University of Nottingham Medical School, NG7 2UH Nottinghamshire, UK. ${ }^{3}$ Department of Physiology and Biophysics, School of Medicine, University for Development Studies, Tamale-Campus, Tamale, Ghana. ${ }^{4}$ Department of Microbiology, Faculty of Bioscience, University for Development Studies, Nyankpala Campus, Tamale, Ghana. ${ }^{5}$ Department of Biochemistry, Cell and Molecular Biology University of Ghana, Legon, Accra, Ghana.

Received: 17 July 2021 Accepted: 27 October 2021

Published online: 04 January 2022

\section{References}

1. Stahl S, Briley M. Understanding pain in depression. Hum Psychopharmacol. 2004;19(Suppl 1):S9-S13. https://doi.org/10.1002/hup.619.

2. Wilson KG, Eriksson MY, D'Eon JL, Mikail SF, Emery PC. Major depression and insomnia in chronic pain. Clin J Pain. 2002;18(2):77-83. https://doi.org/10.1 097/00002508-200203000-00002.

3. Clapper JR, Moreno-Sanz G, Russo R, Guijarro A, Vacondio F, Duranti A, et al. Anandamide suppresses pain initiation through a peripheral endocannabinoid mechanism. Nat Neurosci. 2010;13(10):1265-70. https:// doi.org/10.1038/nn.2632.
4. Gaetani S, Dipasquale P, Romano A, et al. The endocannabinoid system as a target for novel anxiolytic and antidepressant drugs. Int Rev Neurobiol. 2009;85:57-72. https://doi.org/10.1016/S0074-7742(09)85005-8.

5. Ahn K, Douglas SJ and Cravatt BF. Fatty acid amide hydrolase as a potential therapeutic target for the treatment of pain and CNS disorders. Expert Opin Drug Discov 2009; 4(7): 763-784.: 763-784.

6. Di Marzo V, Melck D, Bisogno T, et al. Endocannabinoids: endogenous cannabinoid receptor ligands with neuromodulatory action. $21,: 521$.

7. Mackie K. Cannabinoid receptors: where they are and what they do. J Neuroendocrinol. 2008;20(Suppl 1):10-4. https://doi.org/10.1111/j.1365-282 $6.2008 .01671 x$

8. Graham ES, Ashton JC and Glass M. Cannabinoid Receptors: A brief history and what not. Front Biosci (Landmark Ed) 2009; 14: 944-957. DOl: https://doi.org/1 0.2741/3288, Cannabinoid Receptors: A brief history and "what's hot", 14.

9. Howlett AC. The cannabinoid receptors. Prostaglandins Other Lipid Mediat. 2002;68-69:619-31. https://doi.org/10.1016/s0090-6980(02)00060-6.

10. Ross RA. Anandamide and vanilloid TRPV1 receptors. Br J Pharmacol. 2003; 140(5):790-801. https://doi.org/10.1038/sj.bjp.0705467.

11. Smart D, Gunthorpe MJ, Jerman JC, Nasir S, Gray J, Muir Al, et al. The endogenous lipid anandamide is a full agonist at the human vanilloid receptor (hVR1). Br J Pharmacol. 2000;129(2):227-30. https://doi.org/10.1038/ sj.bjp.0703050.

12. Zygmunt $P M$, Petersson J, Andersson DA, Chuang $H H$, Sørgård $M$, di Marzo $V$, et al. Vanilloid receptors on sensory nerves mediate the vasodilator action of anandamide. Nature. 1999;400(6743):452-7. https:// doi.org/10.1038/22761.

13. Deutsch DG, Chin SA. Enzymatic synthesis and degradation of anandamide, a cannabinoid receptor agonist. Biochem Pharmacol. 1993;46(5):791-6. https://doi.org/10.1016/0006-2952(93)90486-g.

14. Basile AS, Hanus L, Mendelson WB. Characterization of the hypnotic properties of oleamide. Neuroreport. 1999;10(5):947-51. https://doi.org/10.1 097/00001756-199904060-00010.

15. Cheer JF, Cadogan AK, Marsden CA, Fone KC, Kendall DA. Modification of 5HT2 receptor mediated behaviour in the rat by oleamide and the role of cannabinoid receptors. Neuropharmacology. 1999;38(4):533-41. https://doi. org/10.1016/s0028-3908(98)00208-1.

16. Cravatt BF, Prospero-Garcia O, Siuzdak G, Gilula NB, Henriksen SJ, Boger DL, et al. Chemical characterization of a family of brain lipids that induce sleep. Science. 1995;268(5216):1506-9. https://doi.org/10.1126/science.7770779.

17. Leggett JD, Aspley S, Beckett SR, et al. Oleamide is a selective endogenous agonist of rat and human CB1 cannabinoid receptors. Br J Pharmacol. 2004; 141(2):253-62. https://doi.org/10.1038/sj.bjp.0705607.

18. Mechoulam R, Fride E, Hanus L, et al. Anandamide may mediate sleep induction. Nature. 1997;389(6646):25-6. https://doi.org/10.1038/37891.

19. Fowler CJ, Naidu PS, Lichtman A, Onnis V. The case for the development of novel analgesic agents targeting both fatty acid amide hydrolase and either cyclooxygenase or TRPV1. Br J Pharmacol. 2009;156(3):412-9. https://doi. org/10.1111/j.1476-5381.2008.00029.x

20. Garavito RM, Malkowski MG, DeWitt DL. The structures of prostaglandin endoperoxide $\mathrm{H}$ synthases-1 and -2. Prostaglandins Other Lipid Mediat. 2002;68-69:129-52. https://doi.org/10.1016/s0090-6980(02)00026-6.

21. Smith WL, DeWitt DL, Garavito RM. Cyclooxygenases: structural, cellular, and molecular biology. Annu Rev Biochem. 2000;69(1):145-82. https://doi.org/1 0.1146/annurev.biochem.69.1.145.

22. Vane JR. Inhibition of prostaglandin synthesis as a mechanism of action for aspirin-like drugs. Nat New Biol. 1971;231(25):232-5. https://doi.org/10.1038/ newbio231232a0

23. Vane JR, Bakhle YS, Botting RM. Cyclooxygenases 1 and 2. Annu Rev Pharmacol Toxicol. 1998;38(1):97-120. https://doi.org/10.1146/annurev.pha rmtox.38.1.97.

24. Sugiura $T$, Kondo S, Sukagawa A, Tonegawa T, Nakane S, Yamashita A, et al. Transacylase-mediated and phosphodiesterase-mediated synthesis of $\mathrm{N}$ arachidonoylethanolamine, an endogenous cannabinoid-receptor ligand, in rat brain microsomes. Comparison with synthesis from free arachidonic acid and ethanolamine. Eur J Biochem. 1996;240(1):53-62. https://doi.org/1 0.1111/j.1432-1033.1996.0053h.x.

25. Abramovitz M, Metters KM. Prostanoid receptors. Ann Rep Med Chem. 1998 33:223-31. https://doi.org/10.1016/S0065-7743(08)61087-8.

26. Fowler CJ, Borjesson M, Tiger G. Differences in the pharmacological properties of rat and chicken brain fatty acid amidohydrolase. $\mathrm{Br} J$ Pharmacol. 2000;131(3):498-504. https://doi.org/10.1038/sj.bjp.0703569. 
27. Naidu PS, Booker L, Cravatt BF, Lichtman AH. Synergy between enzyme inhibitors of fatty acid amide hydrolase and cyclooxygenase in visceral nociception. J Pharmacol Exp Ther. 2009;329(1):48-56. https://doi.org/1 0.1124/jpet.108.143487

28. Sasso O, Bertorelli R, Bandiera T, Scarpelli R, Colombano G, Armirotti A, et al. Peripheral FAAH inhibition causes profound antinociception and protects against indomethacin-induced gastric lesions. Pharmacol Res. 2012;65(5): 553-63. https://doi.org/10.1016/j.phrs.2012.02.012.

29. Bishay P, Schmidt H, Marian C, Häussler A, Wijnvoord N, Ziebell S, et al. Rflurbiprofen reduces neuropathic pain in rodents by restoring endogenous cannabinoids. PLoS One. 2010;5(5):e10628. https://doi.org/10.1371/journal. pone.0010628

30. Duggan KC, Hermanson DJ, Musee J, Prusakiewicz JJ, Scheib JL, Carter BD, et al. (R)-Profens are substrate-selective inhibitors of endocannabinoid oxygenation by COX-2. Nat Chem Biol. 2011;7(11):803-9. https://doi.org/10.1 038/nchembio.663.

31. Hermanson DJ, Hartley ND, Gamble-George J, Brown N, Shonesy BC Kingsley PJ, et al. Substrate-selective COX-2 inhibition decreases anxiety via endocannabinoid activation. Nat Neurosci. 2013;16(9):1291-8. https://doi. org/10.1038/nn.3480

32. Staniaszek LE, Norris LM, Kendall DA, Barrett DA, Chapman V. Effects of COX-2 inhibition on spinal nociception: the role of endocannabinoids. Br J Pharmacol. 2010;160(3):669-76. https://doi.org/10.1111/j.1476-5381.2010.00703.x.

33. Kozak KR, Rowlinson SW, Marnett LJ. Oxygenation of the endocannabinoid, 2-arachidonylglycerol, to glyceryl prostaglandins by cyclooxygenase-2. J Biol Chem. 2000;275(43):33744-9. https://doi.org/10.1074/jbc.M007088200.

34. Rouzer CA, Marnett LJ. Non-redundant functions of cyclooxygenases: oxygenation of endocannabinoids. J Biol Chem. 2008;283(13):8065-9. https://doi.org/10.1074/jbc.R800005200.

35. Windsor MA, Hermanson DJ, Kingsley PJ, Xu S, Crews BC, Ho W, et al. Substrate-selective inhibition of Cyclooxygenase-2: development and evaluation of achiral Profen probes. ACS Med Chem Lett. 2012;3(9):759-63. https://doi.org/10.1021/ml3001616.

36. Glaser ST, Kaczocha M. Cyclooxygenase-2 mediates anandamide metabolism in the mouse brain. J Pharmacol Exp Ther. 2010;335(2):380-8. https://doi.org/10.1124/jpet.110.168831.

37. Kim J, Alger BE. Inhibition of cyclooxygenase-2 potentiates retrograde endocannabinoid effects in hippocampus. Nat Neurosci. 2004;7(7):697-8. https://doi.org/10.1038/nn1262.

38. Prusakiewicz JJ, Duggan KC, Rouzer CA, Marnett LJ. Differential sensitivity and mechanism of inhibition of COX-2 oxygenation of arachidonic acid and 2-arachidonoylglycerol by ibuprofen and mefenamic acid. Biochemistry. 2009;48(31):7353-5. https://doi.org/10.1021/bi900999z.

39. Fowler CJ, Stenstrom A, Tiger G. Ibuprofen inhibits the metabolism of the endogenous cannabimimetic agent anandamide. Pharmacol Toxicol. 1997; 80(2):103-7. https://doi.org/10.1111/j.1600-0773.1997.tb00291.x.

40. Fowler CJ, Tiger $\mathrm{G}$, Stenstrom A. Ibuprofen inhibits rat brain deamidation of anandamide at pharmacologically relevant concentrations. Mode of inhibition and structure-activity relationship. J Pharmacol Exp Ther. 1997; 283(2):729-34.

41. Garle MJ, Clark JS and Alexander SPH. A fluorescence-derivatisation assay for fatty acid amide hydrolase activity. 2005; pA2 Online. E-journal of the British Pharmacological Society.

42. Lowry OH, Rosebrough NJ, Farr AL, Randall RJ. Protein measurement with the Folin phenol reagent. J Biol Chem. 1951;193(1):265-75. https://doi.org/1 0.1016/S0021-9258(19)52451-6.

43. Mana H, Spohn U. Sensitive and selective flow injection analysis of hydrogen sulfite/sulfur dioxide by fluorescence detection with and without membrane separation by gas diffusion. Anal Chem. 2001;73(13):3187-92. https://doi.org/10.1021/ac001049q.

44. De Bank PA, Kendall DA, Alexander SPH. A spectrophotometric assay for fatty acid amide hydrolase suitable for high throughput screening. Biochem Pharmacol. 2005;69(8):1187-93. https://doi.org/10.1016/j.bcp.2 005.01.012.

45. Patricelli MP, Cravatt BF. Fatty acid amide hydrolase competitively degrades bioactive amides and esters through a nonconventional catalytic mechanism. Biochemistry. 1999;38(43):14125-30. https://doi.org/10.1021/bi991876p.

46. Ueda N, Yamanaka K, Terasawa Y, Yamamoto S. An acid amidase hydrolyzing anandamide as an endogenous ligand for cannabinoid receptors. FEBS Lett. 1999;454(3):267-70. https://doi.org/10.1016/s0014-5793 (99)00820-0.
47. Ueda N, Yamanaka K, Yamamoto S. Purification and characterization of an acid amidase selective for $\mathrm{N}$-palmitoylethanolamine, a putative endogenous anti-inflammatory substance. J Biol Chem. 2001;276(38):35552-7. https://doi. org/10.1074/jbc.M106261200.

48. Boger DL, Fecik RA, Patterson JE, Miyauchi H, Patricelli MP, Cravatt BF. Fatty acid amide hydrolase substrate specificity. Bioorg Med Chem Lett. 2000; 10(23):2613-6. https://doi.org/10.1016/s0960-894x(00)00528-x.

49. Wakamatsu K, Masaki T, Itoh F, Kondo K, Sudo K. Isolation of fatty acid amide as an angiogenic principle from bovine mesentery. Biochem Biophys Res Commun. 1990;168(2):423-9. https://doi.org/10.1016/0006-2 91x(90)92338-z.

50. Zaitone SA, El-Wakeil AF, Abou-El-Ela SH. Inhibition of fatty acid amide hydrolase by URB597 attenuates the anxiolytic-like effect of acetaminophen in the mouse elevated plus-maze test. Behav Pharmacol. 2012;23(4):417-25. https://doi.org/10.1097/FBP.0b013e3283566065.

51. Maccarrone M, Bari M, Menichelli A, del Principe D, Finazzi Agrò A. Anandamide activates human platelets through a pathway independent of the arachidonate cascade. FEBS Lett. 1999;447(2-3):277-82. https://doi.org/1 0.1016/s0014-5793(99)00308-7.

52. Bertolacci L, Romeo E, Veronesi M, Magotti P, Albani C, Dionisi M, et al. A binding site for nonsteroidal anti-inflammatory drugs in fatty acid amide hydrolase. J Am Chem Soc. 2013;135(1):22-5. https://doi.org/10.1021/ja3 08733u.

53. Giang DK, Cravatt BF. Molecular characterization of human and mouse fatty acid amide hydrolases. Proc Natl Acad Sci U S A. 1997;94(6):2238-42. https://doi.org/10.1073/pnas.94.6.2238.

54. Piomelli D, Tarzia G, Duranti A, Tontini A, Mor M, Compton TR, et al. Pharmacological profile of the selective FAAH inhibitor KDS-4103 (URB597). CNS Drug Rev. 2006;12(1):21-38. https://doi.org/10.1111/j.1527-3458.2006. 00021.X.

55. Wei BQ, Mikkelsen TS, McKinney MK, et al. A second fatty acid amide hydrolase with variable distribution among placental mammals. J Biol Chem. 2006;281(48):36569-78. https://doi.org/10.1074/jbc.M606646200.

56. Favia AD, Habrant D, Scarpelli R, Migliore M, Albani C, Bertozzi SM, et al. Identification and characterization of carprofen as a multitarget fatty acid amide hydrolase/cyclooxygenase inhibitor. J Med Chem. 2012;55(20):880726. https://doi.org/10.1021/jm3011146.

57. Fowler CJ, Holt S, Tiger G. Acidic nonsteroidal anti-inflammatory drugs inhibit rat brain fatty acid amide hydrolase in a pH-dependent manner. J Enzyme Inhib Med Chem. 2003;18(1):55-8. https://doi.org/10.1080/147563 6021000049726

58. Holt S, Nilsson J, Omeir R, Tiger G, Fowler CJ. Effects of pH on the inhibition of fatty acid amidohydrolase by ibuprofen. Br J Pharmacol. 2001;133(4):51320. https://doi.org/10.1038/sj.bjp.0704113.

59. Bisogno T, Sepe N, Melck D, et al. Biosynthesis, release and degradation of the novel endogenous cannabimimetic metabolite 2-arachidonoylglycerol in mouse neuroblastoma cells. Biochem J. 1997:322(Pt 2):671-7. https://doi. org/10.1042/bj3220671.

60. Hillard CJ, Wilkison DM, Edgemond WS, Campbell WB. Characterization of the kinetics and distribution of $\mathrm{N}$-arachidonylethanolamine (anandamide) hydrolysis by rat brain. Biochim Biophys Acta. 1995;1257(3):249-56. https:// doi.org/10.1016/0005-2760(95)00087-s.

61. Maurelli S, Bisogno T, De Petrocellis L, et al. Two novel classes of neuroactive fatty acid amides are substrates for mouse neuroblastoma 'anandamide amidohydrolase'. FEBS Lett. 1995;377(1):82-6. https://doi.org/1 0.1016/0014-5793(95)01311-3.

62. Patricelli MP, Lashuel HA, Giang DK, Kelly JW, Cravatt BF. Comparative characterization of a wild type and transmembrane domain-deleted fatty acid amide hydrolase: identification of the transmembrane domain as a site for oligomerization. Biochemistry. 1998;37(43):15177-87. https://doi.org/10.1 021/bi981733n.

63. Ueda N, Kurahashi Y, Yamamoto S, Tokunaga T. Partial purification and characterization of the porcine brain enzyme hydrolyzing and synthesizing anandamide. J Biol Chem. 1995;270(40):23823-7. https://doi.org/10.1074/ jbc. 270.40 .23823

64. Desarnaud F, Cadas H, Piomelli D. Anandamide amidohydrolase activity in rat brain microsomes. Identification and partial characterization. J Biol Chem. 1995;270(11):6030-5. https://doi.org/10.1074/jbc.270.11.6030.

65. Dainese E, Oddi S, Simonetti M, Sabatucci A, Angelucci CB, Ballone A, et al. The endocannabinoid hydrolase FAAH is an allosteric enzyme. Sci Rep. 2020;10(1):2292. https://doi.org/10.1038/s41598-020-59120-1. 
66. Holt S, Paylor B, Boldrup L, Alajakku K, Vandevoorde S, Sundström A, et al. Inhibition of fatty acid amide hydrolase, a key endocannabinoid metabolizing enzyme, by analogues of ibuprofen and indomethacin. Eur J Pharmacol. 2007;565(1-3):26-36. https://doi.org/10.1016/j.ejphar.2007.02.051.

67. Scott HE. Anti-inflammatory agents. MERCK veterinary manuals. 2014 Retrieved January 21, 2015 from Dialog database on worldwide web DOl: http://www.merckmanuals.com/vet/pharmacology/anti-inflammatory _agents/nonsteroidal_anti-inflammatory_drugs.html.

68. Dongdem JT, Dawson SP, Alexander SPH. Characterization of [3-(3carbamoylphenyl) phenyl] N-cyclohexyl carbamate, an inhibitor of FAAH: effect on rat liver FAAH and HEK293T-FAAH-2 deamination of oleamide, arachidonamide and stearoylamide. Asian J Pharmacol Toxicol. 2016;04:01-11.

69. Lichtman AH, Naidu PS, Booker $L$, et al. Targetting FAAH and COX to treat visceral pain. FASEB J 2008; 22: . DOl: https://doi.org/10.1096/fasebj.22.1_ supplement.1125.12

70. Guindon J, LoVerme J, De Lean A, et al. Synergistic antinociceptive effects of anandamide, an endocannabinoid, and nonsteroidal antiinflammatory drugs in peripheral tissue: a role for endogenous fattyacid ethanolamides? Eur J Pharmacol. 2006;550(1-3):68-77. https://doi. org/10.1016/j.ejphar.2006.08.045.

71. Naidu PS and Lichtman AH. Synergistic antinociceptive effects of URB597 and diclofenac in a mouse visceral pain model. . In: 17th Annual symposium on the cannabinoids, Vermont International Cannabioid Research Society Burlington, Vermont USA, 2007.

72. Blain H, Boileau C, Lapicque F, Nédélec E, Lœuille D, Guillaume C, et al. Limitation of the in vitro whole blood assay for predicting the COX selectivity of NSAIDs in clinical use. Br J Clin Pharmacol. 2002;53(3):255-65. https://doi.org/10.1046/.0306-5251.2001.01533.x.

73. Mitchell JA, Akarasereenont P, Thiemermann C, Flower RJ, Vane JR. Selectivity of nonsteroidal antiinflammatory drugs as inhibitors of constitutive and inducible cyclooxygenase. Proc Natl Acad Sci U S A. 1993; 90(24):11693-7. https://doi.org/10.1073/pnas.90.24.11693.

74. Rao P, Knaus EE. Evolution of nonsteroidal anti-inflammatory drugs (NSAIDs): cyclooxygenase (COX) inhibition and beyond. J Pharm Pharm Sci. 2008;11: 81s-110s. https://doi.org/10.18433/33t886

75. Warner TD, Giuliano F, Vojnovic I, Bukasa A, Mitchell JA, Vane JR. Nonsteroid drug selectivities for cyclo-oxygenase-1 rather than cyclooxygenase-2 are associated with human gastrointestinal toxicity: a full in vitro analysis. Proc Natl Acad Sci U S A. 1999;96(13):7563-8. https:// doi.org/10.1073/pnas.96.13.7563.

\section{Publisher's Note}

Springer Nature remains neutral with regard to jurisdictional claims in published maps and institutional affiliations.

Ready to submit your research? Choose BMC and benefit from:

- fast, convenient online submission

- thorough peer review by experienced researchers in your field

- rapid publication on acceptance

- support for research data, including large and complex data types

- gold Open Access which fosters wider collaboration and increased citations

- maximum visibility for your research: over $100 \mathrm{M}$ website views per year

At $\mathrm{BMC}$, research is always in progress.

Learn more biomedcentral.com/submissions 